\title{
Estimation of Genetic Parameters for Yield Associated Traits and Principal Component in Advance Breeding Lines of Soybean (Glycine max. (L.) Merrill)
}

\author{
Vikas Verma*, M. K. Shrivastava, Shrishti Mehra, Pawan K. Amrate and R. B. Yadav \\ Department of Plant Breeding and Genetics, Jawaharlal Nehru Krishi Vishwa Vidhyalaya, \\ Jabalpur, Madhya Pradesh, India \\ *Corresponding author
}

\section{A B S T R A C T}

Keywords

Correlation, Path

analysis,

Heritability,

Principal

component analysis

Article Info

Accepted:

18 December 2020

Available Online:

10 January 2021
Soybean [Glycine $\max$ (L.) Merrill] is highly nutritious with neutraceutical valued legume crop grows across the world. Information on different genetic estimates is used to select desirable traits and genotypes for crossing programme. The present investigation was undertaken to estimate different genetic parameters i.e. genetic variability, heritability, character association and principal component on thirty four advanced breeding lines of soybean along with two checks sown in Randomized block Design during Kharif, 2018 at JNKVV, Jabalpur. The highest PCV and GCV (41.16 and $40.43 \%)$ were recorded for number of seeds per pod. Genetic advance as percentage of mean was high $(>75 \%)$ for number of seeds per plant and number of seeds per pod. The number of pods per plant was highly significantly correlated with number of seeds per plant $(0.79 * *)$. Path coefficient analysis was also revealed that substantial higher positive direct effect of number of seeds per plant and number of seeds per pod on seed yield. Out of five principle components, PC1 had the highest variance percentage with Eigen value of 2.17. Number of seeds per plant contributed highest (64\%) in PC1. Hence, all these traits could be utilized in soybean crossing programme for further yield improvement.

\section{Introduction}

Soybean [Glycine max. (L.) Merrill] is one most important oilseed crops grown across the world. It is a highly nutritive and energy rich legume contains 39.4- $44.4 \%$ protein and 14.0-18.7\% edible oil (Sharma et al., 2014). Apart from this, the presence of good amount of vitamins, minerals, salts and essential amino acids makes it very health beneficial food. It serves as both pulse and oil seed crop and gives 2-3 times more protein yield than other pulses (Nawab Ali, 1992). Being a legume, it fixes atmospheric nitrogen and adds about $65-100 \mathrm{~kg} \mathrm{~N} / \mathrm{ha} /$ year to the soil which helps increase the yields of following non-legume crops (Fujitha et al., 1992).Due to its various uses it is rightly called as "Golden gift of nature to mankind".

In India, it is grown in 10.96 million hectare with production of 13.46 million hectare and 
productivity of $1228 \mathrm{~kg} / \mathrm{ha}$ (Anonymous, 2018). India ranks fourth in terms of soybean area in the world behind only to USA, Brazil and Argentina. Madhya Pradesh has played a vital role ever in the development and expansion of soybean cultivation and contributes substantially in all respect and is known as "Soya State". The yield level of soybean in our country is hovering around 1.2 ton/ha which is quite low in comparison to the major soybean growing countries of the world. However, it's per day yield is more than the major soya growing countries. Yield is a complex entity influenced by several phenological, physiological, pod and yield characters and environment. This may be due to narrow genetic base of the released varieties as well as their lower genetic yielding potential and stability to varied climatic changes. The most important goal of many soybean breeding programmes is the development of stable lines with improved seed yield with climatic resilient ability. The three major components of soybean yield viz., number of pods per plant; numbers of seeds per plant and seed size are easily identifiable characters which have assisted selection for higher yield. However, an increase in yield often results from the increase in the number of seeds per pod (Zhu and Sun, 2006). In our investigation on 34 soybean genotypes, we studies various genetic parameter for essential yield traits, their association with the seed yield and principal component analysis using " $R$ " software for statistical analysis.

\section{Materials and Methods}

The experimental material comprised of 34 genotypes including two checks of soybean viz; JS 21-79, JS 21-82, JS 22-13, JS 22-15, JS 21-49, JS 22-32, JS 22-53, JS 22-56, JS 21-83, JS 22-19, JS 22-42, JS 22-05, JS 2212, JS 22-14, JS 22-23, JS 22-16, JS 22-53, JS 22-52, JS 22-60, JS 22-39, JS 21-84, JS 2186, JS 21-85, JS 21-87, JS 22-61, JS 21-10, JS
21-05, JS 22-21, JS 21-24, JS 21-22, JS 2108, JS 97-52 and JS 20-69 (c), JS 20-98 (c). The experiment was laid out in a randomized complete block design with three replications at the Seed Breeding Farm, JNKVV, Jabalpur (M.P.) during the Kharif, 2018. Size of each plot was kept $3.0 \mathrm{~m} \times 1.6 \mathrm{~m}$ ( 3 rows of $3 \mathrm{~m}$ length) and $40 \mathrm{~cm}$ row to row distance. Five quantitative characters were recorded on the basis of three random competitive plants selected from each line in each replication. Analysis of variance on different characters was carried out as per the standard procedure of Fisher, 1963. Genotypic and phenotypic coefficients of variation were estimated according to Burton and Devane, 1953. Heritability in broad sense and genetic advance were worked out as per Hanson et al., (1956) and Johnson et al., (1955), respectively. Phenotypic and genotypic correlationand path coefficients of variation were computed based onthe method given by Dewey and Lu (1959) and principal component analysis using $\mathrm{R}$ software version 3.6.0 (R Project for Statistical Computing, http://www.r-project.org/).

\section{Results and Discussion}

\section{Genetic variability and character association}

The genetic variability is the raw material of plant breeding on which selection acts to evolve superior promising genotypes. Thus, higher the amount of variation present for a concerned character in the breeding materials, greater is the scope for its improvement through selection. The phenotypic coefficient of variation was significantly higher in magnitude than that of genotypic coefficient of variation for all the characters under study (Table.1). Phenotypic coefficient of variation (PCV) and genotypic coefficient of variation (GCV) are categorized as low $(<10 \%)$, moderate $(10-20 \%)$ and high $(>20 \%)$ as 
suggested by Sivasubramanian and Madhavamenon (1973).

The analysis of variance revealed that the mean squares were significant for all the five yield attributing traits. The values of phenotypic coefficient of variation (28.77 to 41.16) were higher than the genotypic coefficient of variation (27.78 to 40.43) exhibited that environmental influence was lesser in the expression of all traits (Table1). Highest PCV and GCV were recorded for number of seeds per pod (41.16 and 40.43) and number of seeds per plant (37.47 and 36.98), indicating a high variability and ample scope for selecting traits for development of varieties (Ghodhrati et al.,2013) and Mehra et al., (2020) also reported highest PCV and GCV for number of pods/plant

Heritability in broad sense was estimated for all the traits under study and presented in
Table-1. Heritability estimates were classified as high (>70\%), moderate (50-70\%) and low (< 50\%). High heritability coupled with genetic advance (percent of mean) was observed for number of seeds per pod and number of primary branches (Table-1). This suggested the preponderance of additive gene action with low environmental influence. Heritability estimates along with genetic advance are usually more helpful in predicting the genetic gain than heritability estimates alone (Johnson et al., 1955). Similar results were also obtained for number of primary branches, number of pods per plant by Ramana et al., (2000), and seed yield by Jain et al., (2017), and number of pods per plant by Neelima et al.(2018). Mehra et al., (2020) also reported high heritability couple with high genetic advance for number of primary branches, number of pods/plant and number of seeds/ plant.

Table.1 Genetic Variability analysis of five traits for34 soybean genotypes during Kharif 2018

\begin{tabular}{|c|c|c|c|c|c|c|c|}
\hline \multirow[t]{2}{*}{ Traits } & \multirow[t]{2}{*}{ Mean } & \multicolumn{2}{|c|}{ Range } & \multicolumn{2}{|c|}{ CV } & \multirow[t]{2}{*}{$h^{2}(b s) \%$} & \multirow[t]{2}{*}{ GAM\% } \\
\hline & & Min. & Max. & GCV\% & PCV\% & & \\
\hline Number of primary branches & 14.97 & 10.0 & 22.0 & 30.56 & 31.55 & 93.82 & 60.97 \\
\hline Number of pods per plant & 107.38 & 62.0 & 154.0 & 27.78 & 28.77 & 93.2 & 55.24 \\
\hline Number of seeds per plant & 255.85 & 116.0 & 392.0 & 36.98 & 37.47 & 97.44 & 75.21 \\
\hline Number of seeds per pod & 8.35 & 6.0 & 11.0 & 40.43 & 41.16 & 96.45 & 81.79 \\
\hline Seed yield & 1.03 & 0.62 & 1.64 & 29.15 & 29.16 & 99.97 & 60.04 \\
\hline
\end{tabular}

Table. 2 Correlation studies for yield and yield contributing traits for 34 soybean genotypes

\begin{tabular}{|c|c|c|c|c|c|}
\hline Traits & $\begin{array}{c}\text { Number of } \\
\text { primary branches }\end{array}$ & $\begin{array}{c}\text { Number of pods } \\
\text { per plant }\end{array}$ & $\begin{array}{c}\text { Number of seeds } \\
\text { per plant }\end{array}$ & $\begin{array}{c}\text { Number of seeds } \\
\text { per pod }\end{array}$ & $\begin{array}{c}\text { Seed } \\
\text { yield }\end{array}$ \\
\hline $\begin{array}{c}\text { Number of } \\
\text { primary branches }\end{array}$ & 1 & 0.12 & $0.42^{*}$ & $0.5^{*}$ & -0.18 \\
\hline $\begin{array}{c}\text { Number of pods } \\
\text { per plant }\end{array}$ & & 1 & $0.79 * *$ & -0.07 & 0.12 \\
\hline $\begin{array}{c}\text { Number of seeds } \\
\text { per plant }\end{array}$ & & & 1 & $0.38^{*}$ & 0.23 \\
\hline $\begin{array}{c}\text { Number of seeds } \\
\text { per pod }\end{array}$ & & & & 1 & 0.26 \\
\hline Seed yield & & & & & 1 \\
\hline
\end{tabular}

** Correlation is significant at the 0.01 level, * Correlation is significant at the 0.05 level 
Table.3 Path analysis studies for yield and yield contributing traits for 34 soybean genotypes

\begin{tabular}{|c|c|c|c|c|c|}
\hline Traits & $\begin{array}{c}\text { Number of } \\
\text { primary } \\
\text { branches }\end{array}$ & $\begin{array}{c}\text { Number of } \\
\text { pods per } \\
\text { plant }\end{array}$ & $\begin{array}{c}\text { Number of } \\
\text { seeds per } \\
\text { plant }\end{array}$ & $\begin{array}{c}\text { Number of } \\
\text { seeds per } \\
\text { pod }\end{array}$ & Seed yield \\
\hline $\begin{array}{c}\text { Number of primary } \\
\text { branches }\end{array}$ & $-\mathbf{- 0 . 5 1}$ & -0.01 & 0.16 & 0.18 & -0.18 \\
\hline $\begin{array}{c}\text { Number of pods per } \\
\text { plant }\end{array}$ & -0.06 & $\mathbf{- 0 . 0 9}$ & 0.3 & -0.03 & 0.12 \\
\hline $\begin{array}{c}\text { Number of seeds per } \\
\text { plant }\end{array}$ & -0.21 & -0.07 & $\mathbf{0 . 3 8}$ & 0.14 & 0.23 \\
\hline $\begin{array}{c}\text { Number of seeds per } \\
\text { pod }\end{array}$ & -0.26 & 0.01 & 0.14 & $\mathbf{0 . 3 6}$ & 0.26 \\
\hline
\end{tabular}

Table.4 Principal component analysis of five traits for 34 soybean genotype

\begin{tabular}{|c|c|c|c|c|c|}
\hline Traits & PC1 & PC2 & PC3 & PC4 & PC5 \\
\hline Number of primary branches & 0.42 & -0.53 & -0.33 & 0.65 & -0.11 \\
\hline Number of pods per plant & 0.47 & 0.56 & -0.26 & -0.07 & -0.63 \\
\hline Number of seeds per plant & 0.64 & 0.21 & -0.08 & -0.16 & 0.72 \\
\hline Number of seeds per pod & 0.4 & -0.55 & 0.36 & -0.57 & -0.28 \\
\hline Seed yield & 0.2 & 0.22 & 0.83 & 0.46 & -0.04 \\
\hline Eigenvalue & 2.17 & 1.29 & 1.13 & 0.32 & 0.09 \\
\hline Variance percent & 43.37 & 25.90 & 22.52 & 6.36 & 1.85 \\
\hline Cumulative.variance.percent & 43.37 & 69.27 & 91.79 & 98.15 & 100.00 \\
\hline
\end{tabular}

Fig.1 Biplot analysis depicting principal component for five traits of soybean genotype

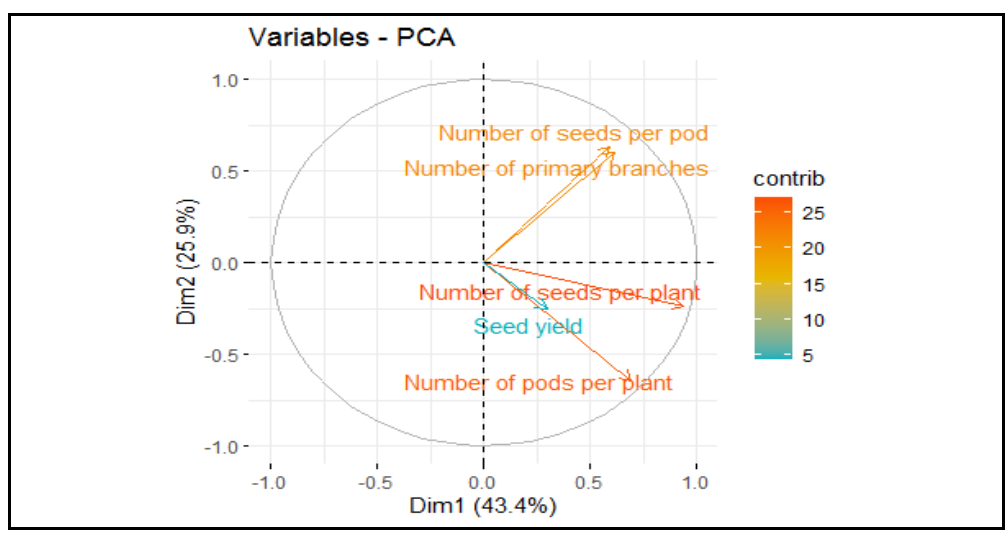

Pearson Correlation coefficient between traits indicates the magnitude of association and forms the basis of selection criterion and helps the breeder in selecting desirable one for further varietal improvement. In the present investigation, correlations were worked out in all possible character combination of all the soybean genotypes and the inherent association of number of pods per plant number of seeds per plant was found to 
had highest significant correlation with number of seeds per plant followed by number of primary branches with number of seeds per pod and number of seeds per plant with number of seeds per pod, respectively. Similar finding were also reported by Ghodhrati et al., (2013). Mehra et al., (2020) also found highest significant correlation between number of pods and seed yield per plant.

Whereas, Path coefficient analysis (Table-3) revealed, substantially higher positive direct effect of number of seeds per plant has the direct positive effect on seed yield followed by number of seeds per pod whereas, other traits has direct but negative effect on seed yield. The high magnitude of negative direct effect on seed yield per plant was exhibited by number of primary branches (Table-3). Similar findings have also been reported by Machikowa and Laosuwan (2011) for fresh weight at full flowering, Salami and Moradi (2012) for number of seed per plant, Jain et al., (2015) for biological weight and Mishra et al., (2015) for number of seed per plant, 100 seed weight and number of pods per plant.

\section{Principal component analysis}

The results of principal component analysis were presented in the table-4. Total five principle components were formed for 34 genotypes. It was found that the PC1 had the highest variance percentage with Eigen value of 2.17. The principle component (PC) analysis partitioned the total variance into 4 PCs contributing maximum to the total diversity among the genotypes due to the study of various traits. Principal component analysis showed first three PCs having Eigen value $>1$ explaining $91.79 \%$ of the total variation (Table-4). The first principal component (PC1) which explained $43.37 \%$ variation was associated mainly with number of seeds per plant, number of pod per plant and number of primary branches. The second principal component (PC2) was responsible for about $25.90 \%$ of the variation and was mainly related to number of pods per plant, while the third principal component (PC3) was responsible for about $22.52 \%$ of the variation and mainly related to number of seeds per pod.

Where, number of seeds per plant contributed about $(64 \%)$ towards PC1 followed by number of pods per plant, number of primary branches, number of seeds per pod and seed yield respectively, It can also be observed through biplot analysis shown in figure-1.

Principal component analysis is often used to reduce the variables and genotypes of groups. Among these biometrical procedures, the main advantage of principal component analysis (PCA) is that each genotype can be attributed to only one group and also reflects the importance of the greatest contribution to the total variation in each differentiation axis (Sharma, 1998). Analysis of the principle components divides the total variance into several factors. By removing the relationship between the main component variables and the Eigen value, it reduces the dimensionality of multivariate data representing the variance of the main component (Matus, 1999).

On the basis of above findings, it is evident that substantial genetic variability was envisaged for yield and its attributing traits in most of the genotypes under study. Therefore, these traits governing genotypes should be considered while selecting superior and desirable plants for further evolving promising genotypes in soybean breeding programme.

\section{Acknowledgements}

The authors gratefully acknowledged the support of technical and field staff of AICRP 
on Soybean and Prof. \& Head, Department of plant Breeding and Genetics for their kind guidance.

\section{References}

Anonymous, 2018. Directors Report, Indian Institute of Soybean Research, Indore, pp. 327.

Burton G.W.1952.Quantitative inheritance in grasses.Proceedings of the 6th Grassland Congress, 1: 277-285.

Dewey J R and Lu K H.1959. A correlation and path co-efficient analysis of components of crested wheat seed production. Agronomy Journal, 51: 515-518.

Fisher R A and Yates F. 1963. Statistical tables for biological, agricultural and medical research. Oliver and Boyd, London.

Fujitha K, Ofosus - Bady K.G. and Ogatas. 1992 Biological nitrogen fixation in mixed legume - cereals cropping system. Plant and Soil 141 (1-2): 155175.

Ghodrati G R, Sekhavat R, Mahmood S H, Gholami A. 2013. Evaluation of correlations and path analysis of components seed yield in soybean. International Journal of Agriculture:Research and Review. Vol.3 No.4 pp.795-800

Hanson W D, Robinson H F and Comstock R E. 1956. Biometrical studies of yield segregating population Korean lespandeza. Agronomy Journal, 48: 268-272.

Jain R K, Joshi A, Chaudhary H R, Dashora A and Khatik C L 2017. Study on genetic variability, heritability and genetic advance in soybean [Glycine max (L.) Merrill]. Legume Research, DOI: $10.18805 / L R-3874$.

Jain S, Srivastava SC, Singh SK, Indapurkar YM and Singh BK. 2015.Studies on genetic variability, character association and path analysis for yield and its contributing traits in soybean [Glycine max (L.) Merrill] Legume Research 38 (2): 182-184.

Johnson H W, Robinson H F and Comstock R E. 1955. Estimate of genetic and environmental variability in soybean. Agronomy Journal, 47: 314-318

KC, R.B., Sharma, M.D., Panthee D., \& Gautam, D.M. 2001.Physiomorphological characterization of indigenous garlic germplasm of Nepal. Master Thesis. Institute of Agriculture and Animal Science Rampur, Nepal.

Machikowa T and Laosuwan P. 2011. Path coefficient analysis for yield of early maturing soybean. Journal of Science and Technology 33(4): 365-368.

Matus, I., Gonzalez, M.I., \& del. Pozo A. 1999. Evaluation of phenotypic variation in a Chilean collection of garlic clones using multivariate analysis. Plant genetic resources Newsletter, 117, 31-36.

Mehra S, Shrivastava M K, Amrate Pawan K and Yadav R B (2020) Studies on variability, correlation coefficient and path analysis for yield associated traits in soybean [Glycine max (L.) Merrill]. Journal of Oilseeds Research, 37(1): 56-59.

Mishra S, Shrivastava AN, Jha A, Tantaway S, 2015.Correlation and Path Coefficient Analysis of Advance Breeding Lines of Soybean. Annals of Plan and Soil Research 17 (Special Issue): $34-37$.

Nawab Ali.1992 Soybean food potential and its exploitation for Indian situation. Agricultural situation in India 17: 395 402.

Neelima G, Mehtre S P and Narkhede G W. 2018. Genetic variability, heritability and genetic advance in soybean. International Journal of Pure Applied 
Bioscience, 6(2):1011-1017.

Ramana M V, Pramilarani B and Satyanarayana A. 2000. Genetic variability, correlation and path analysis in soybean. Oilseeds Research Journal, 17(1): 32-35.

Salimi S and Moradi S. 2012. Effect the correlation, regression and path analysis in soybean genotypes [Glycine max (L.) Merrill] under moisture and normal condition. International Journal of Agronomy and Plant Production 3(10): 447-454.

Sharma S, Kaur M, Goyal R, and Gill B S. 2014.Physical characteristics and nutritional composition of some new soybean (Glycine max (L.) Merrill) genotypes, Journal of Food Science and Technology 51 (3): 551-557.

Sharma, J.R. 1998.Statistical and biometrical techniques in plant breeding. New Age International Limited Publishers, New Delhi, India

Sivasubramanian S and Madhavamenon P. 1973. Combining ability in rice. Madras Agricultural Journal 60: 419421.

Zhu BG and Sun YR. 2006. Inheritance of the Four Seeded Pod Trait in a Soybean Mutant and Marker assistant Selection for this Trait. Plant Breeding 125: 405407.

\section{How to cite this article:}

Vikas Verma, M. K. Shrivastava, Shrishti Mehra, Pawan K. Amrate and Yadav, R. B. 2021. Estimation of Genetic Parameters for Yield Associated Traits and Principal Component in Advance Breeding Lines of Soybean (Glycine max. (L.) Merrill). Int.J.Curr.Microbiol.App.Sci. 10(01): 2704-2710. doi: https://doi.org/10.20546/ijcmas.2021.1001.314 